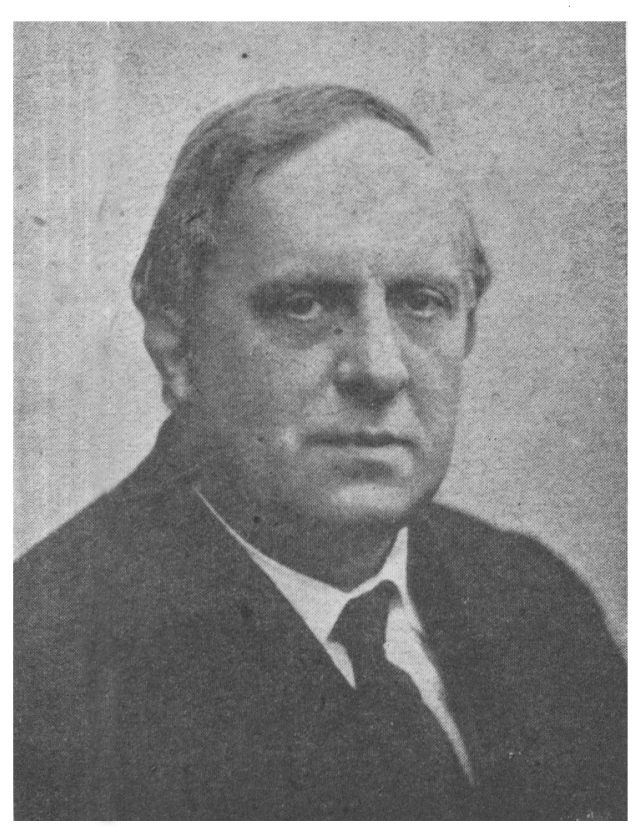

\title{
FREDERICK WILLIAM LANCHESTER
} I868-1946

$\mathrm{B}_{\mathrm{L}}^{\mathrm{Y}}$ THE DEATH of Frederick William Lanchester aviation has lost one who will take a high place on the roll of aeronautical fame.

Born only a few months after the Society had held the first aeronautical exhibition ever held in this country. Lanchester was educated privately and at the Royal College of Science.

In 1889 Lanchester became Assistant Works Manager at Messrs. T. B. Barker's of Saltley, Birmingham, and turned his energies towards the development of the gas engine, producing his well-known gas engine starter, and developing engines of higher speeds than had been in use. It was at this time that he began to work in close association with Sir Dugald Clark.

In 1894 he began the construction of the first Lanchester motor car and in 1899 the Lanchester Motor Company was formed, with Lanchester as Chief Engineer and General Manager.

These years of development showed his remarkable ability and foresight. The Motor Car Industry, indeed, owes as great a debt to Lanchester as does aeronautics. To him were due the epicyclic change-speed gear, pre-selector gear, wire wheels, electric ignition, directdriven top gear and normal transmission on the rear axle.

From 1904 to 1914 he became Consulting Engineer to the Lanchester Company, from 1909- to 1929 he was Consulting Engineer and Technical Adviser to the Daimler Company and from. 1928 to 1930 Consulting Engineer to William Beardmore's on Diesel engines.

In 1910 he brought out his crankshaft damper and in 1911 his harmonic balancer, which were important contributions to the problem of torsional oscillation of internal combustion engines. His pendulum accelerometer for measuring and recording tractive and braking effort appeared about this time and his gyroscopic true plumb and turn indicator was widely used in the Air Force in the 1914-18 War.

An indication of his wide interest was the production in 1927 of an acoustic tube moving-coil loud speaker and diffractaphone aperture which ensured the most perfect distribution of tones of different pitch in a concert hall or in the open air. He was the 
author of papers which varied from Aerodynamics to the Theory of Dimensions, from Gearing to Relativity, from The Energy Balance Sheet of the Internal Combustion Engine to Discontinuities in the Normal Field of Vision.

It is in the field of aeronautics, however, that the fame of Lanchester will surely rest.

At the age of 26, in 1894, he read to the Birmingham Natural History and Philosophical Society a paper in which he first put forward the now well-known conception of the vortex or circulation theory of sustentation in flight. It was a paper of the highest importance. During the next three years Lanchester revised it and submitted it in 1897 to the Physical Society, which rejected it, and he had to wait until the publication of his own books on Aerodynamics and Aerodonetics in 1907.

These two books form the foundations of flight as we know it to-day. They revealed an insight into aerodynamic problems which was all the more astounding when so little was known.

On the occasion of the award of the 1945 James Watt International Medal by the Institute of Mechanical Engineers to Lanchester, Sir Melvill Jones, Chairman of the Aeronautical Research Council, said:-

"The ideas and theories contained in the volumes have since been extended and developed by subsequent authors and some have been restated in mathematical terms of a more conventional kind than those used by the author. For this reason many who now make constant use of Lanchester's ideas may not appreciate fully from whom they originated, but no one conversant with the science as it now stands can fail to be impressed, on reading the volumes, with the author's astounding vision and grasp of the subject, at a time when very little was known about it and the experimental data, beyond what he himself had obtained with the simplest apparatus, were almost non-existent."

It was in his Aerodynamics that Lanchester published the first statement about induced drag and showed the generation of the circulatory motion in the air, which takes the form of a pair of vortices from the wing tips. In 1915 in a further paper, he showed that induced drag depended primarily on wing span.

Lanchester also drew attention in his book to the importance of skin friction, which Langley had asserted was of little importance. His ideas at the time were revolutionary and it took many years before they were translated into the streamline aircraft of the present day.

In this astonishing volume on Aerodynamics, Lanchester also discussed scale effect and explained the use of Reynolds Number, sometimes wrongly claimed for Lord Rayleigh, who himself did not claim priority.

The first volume to be published in 1907, under the title Aerodonetics, laid down the main features of stability and control, entirely as the result of his own observations on small gliding models, a very remarkable achievement.

As early as 1897 Lanchester filed a patent (No. 3608) disclosing some of the results of his research. Here he mentioned, which was not obvious at the time, that in an aeroplane the tail plane adjustment controls the speed. He also made reference to wing warping, though it was not in such precise terms as to upset the claim of the Wright brothers. 
Space does not permit a review of the many papers Lanchester published. Sufficient has been said, however, to indicate the outstanding quality of his work and with the years his reputation will continue to grow. His was a master mind.

Lanchester's work has already received international recognition. He was a Fellow of the Royal Society, and an Honorary Doctor of Laws, an Honorary Fellow of the Institute of Mechanical Engineers, and of the Royal Aeronautical Society. He was awarded the Gold Medal of the Society in 1926, when he read the Wilbur Wright Memorial Lecture, the Daniel Guggenheim Gold Medal in 1931 and the Ewing Medal of the Institution of Civil Enginéers in 1941.

From 1909 to 1920 he was a member of the Advisory Committee on Aeronautics and contributed many papers to its Reports and Memoranda.

Lanchester will take his place with such figures as Sir George Cayley and Stringfellow in the history of British aeronautics. He. was a man of great personality, a brilliant scientist and an outstanding engineer. He had an independence of outlook and a freedom of spirit which brought great opposition from the vested minds which he fought so long and so ably.

Few people knew that Lanchester was also a poet who published privately two slim volumes of verse under the name of Paul Netherton Herries. In one he wrote:-

" He is no more!

Whose countless friends, belov'd of him, stand silent now;

Born to high achievement, yet frugally he lived,

Bearing the yoke of service here with dignity.

His soul was in his work, which, living on, bears fruit:

So doth a soul attain to immortality."

It is a fitting epitaph to a great pioneer. 